\title{
The larva of Chiron senegalensis and comments on its relationships with other Scarabaeoidea (Coleoptera: Chironidae)
}

\author{
Jean-Bernard HUCHET and Jean-Pierre LUMARET \\ Laboratoire de Zoogéographie, Université Paul Valéry Montpellier III, Route de Mende, F- 34199 Montpellier cedex 5, France; \\ e-mail: jbhuchet@club-internet.fr; jean-pierre.lumaret@univ-montp3.fr
}

Key words. Coleoptera, Scarabaeoidea, Chironidae, Chiron senegalensis, larva, description

\begin{abstract}
After a brief presentation of some historical, taxonomical and biological data on the Chironidae, the third instar larva of Chiron senegalensis Hope \& Westwood, 1845 is described and illustrated on the basis of larval characteristics. The systematic position of the genus Chiron Mac Leay, 1819 within the Scarabaeoidea complex is discussed.
\end{abstract}

\section{INTRODUCTION}

Although it is now clearly established that the Chironidae forms a very peculiar and morphologically isolated group within the Scarabaeoidea (Huchet, 2000), its relationships with other groups remains uncertain or even enigmatic. A recent discovery in Senegal gave us the opportunity to describe the larva of Chiron senegalensis Hope \& Westwood, 1845 and, using larval characters, to discuss the affinities of Chiron Mac Leay, 1819 with the main groups of Scarabaeoidea.

\section{HISTORY AND TAXONOMY OF CHIRONIDAE}

There have been many controversies in the past about the systematic position of species currently belonging to Chiron (Huchet, 2000). Fabricius (1798) was the first to describe a species, as Scarites cylindrus. Few years later, that species was placed either by Illiga (1801) in the genus Passalus Fabricius, 1792, at that time still in the Lucanidae, or by Fabricius (1801) in Sinodendron Hellwiy, 1792. Latreille (1817: 292), in a paper dealing with Passalus, suggested that a new combination was required for the species described by Fabricius. The genus Chiron was proposed two years later by Mac Leay (1819), who considered this taxon to be close to the Platypodidae.

Latreille $(1825,1829)$, taking into account the structure of the labrum and mandibles (well sclerotised and visible beyond the clypeus in dorsal view), considered Chiron to be closely related to Aegialia Latreille, 1807. This opinion was accepted by subsequent authors, albeit with some reservations. Until recently, Chiron was considered to belong to the Aphodiidae or Aegialiidae (Balthasar, 1963 ) and the only genus in either a tribe or subfamily. Paulian (1976) was the first author to treat Chiron as forming a distinct family.

In a recent paper, Huchet (2000) reviewed all these suggestions and showed that the adult morphology of Chiron (mouthparts, mandibles, genitalia...) was suffi- ciently distinctive to warrant the family status suggested by Paulian. Two new genera recently proposed by Huchet (2000) have been reviewed (Huchet, 2002a, b). Adults of Chironidae are easily recognised by their cylindrical shape, 9-segmented antennae, labrum produced beyond the clypeus, prominent mandibles and mesothorax distinctly pedunculate (Fig. 1).

\section{BIOLOGY AND DISTRIBUTION}

Little is known about the biology of these insects. Adults are nocturnal* and are most often collected at light traps, sometimes in large numbers. In Mauritania ( $P$. Bruneau de Miré, pers. com.) adults of Chiron senegalensis and Theotimius grandis (Gory, 1830) (Col. Chironidae) were found together in the vicinity of Nyayes (temporary ponds) under rotting trunks of Acacia nilotica (L.) (Leguminosae), in waterlogged soil. Field observations of one of us in Senegal during the rainy season (J.B.H.) indicate that, during the day, adults and larvae of Chiron senegalensis live in subterranean burrows in the vicinity of temporary ponds. The adults appear to be probably gregarious since they were often found in adjacent tunnels near the soil surface (approx. depth: 1-2 cm). Larvae were collected in the same place but living in suboval cells, approximately at $3-5 \mathrm{~cm}$ beneath the soil surface. Based on an examination of the hind gut contents of adults, R. A. Crowson (pers. com., 1998) concluded that species of Chiron feed on terrestrial filamentous algae, and have habits similar to Bledius Leach, 1819 or Heterocerus Fabricius, 1792 species.

The Chironidae includes 3 genera (Huchet, 2000) and about 25 species mainly distributed in Africa south of the Sahara; with some species in Madagascar, Pakistan, India (as far as Assam), Bangladesh and Sri Lanka. The presence of species of Chiron in the Mediterranean Basin (Tunisia, Sicily and Corsica) is very likely the result of accidental introductions.

\footnotetext{
* Observations on adults of Chiron senegalensis reared in the laboratory confirm their nocturnal habits. They concealed themselves during the day in subterranean burrows, and were very active on the soil surface at night.
} 


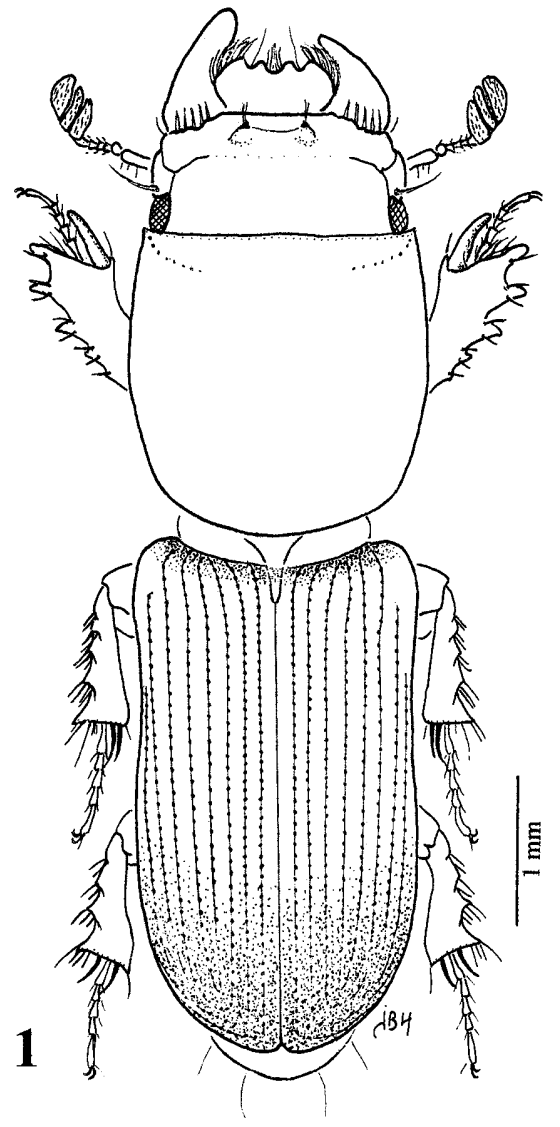

Fig. 1. Chiron senegalensis Hope \& Westwood, adult habitus.

\section{MATERIAL AND METHODS}

The description is based on the following material: 23 thirdinstar larvae collected with living adults in sandy-clayey soil (approx. 40\% sand; 60\% clay, essentially kaolinite and montmorillonite) near the banks of pools, during the summer of 1996, at Richard-Toll $\left(16^{\circ} 28^{\prime} \mathrm{N}, 15^{\circ} 35^{\prime} \mathrm{W}\right)$ and Dagana $\left(16^{\circ} 28^{\prime} \mathrm{N}\right.$, $15^{\circ} 41^{\prime} \mathrm{W}$ ), Senegal (Figs 31, 32). All material was fixed in KAAD solution (Carne, 1951). Thoracic spiracles were cleared in $\mathrm{KOH}$ then coloured with black chlorazol (Carayon, 1969). All photographs of larval mouthparts and other body structures were taken by P. E. Skelley (Florida State Collection of Arthropods). The specimens were dried in a critical point drier and photographed using a scanning electron microscope (Hitachi S-4000 FE-SEM). The larval terminology follows Böving \& Craighead (1931), Böving (1936), Ritcher (1966), Kim \& Lumaret (1988) complemented by Verdú \& Galante (1997). The classification of Scarabaeoidea used in this paper follows Paulian (1988).

Acronyms: A - antenna; A1-A10 - abdominal segments; ACP - acanthoparia; ACR - acroparia; ACS - anterior clypeal setae; AFS - anterior frontal setae; ASL - anal slit; ASTS anterior stipe setae; B - brustia; BA - barbula; C - clypeus; CA - campus; CAR - cardo; CFS - clypeo-frontal suture; CL claw; CLGIS - central lobe glossae setae; CLI - clithrum; CPAS - chaetoparial setae; CSSO - cone-shape sensory organ; CX - coxa; DAGS - dorso-apical setae of galea; DAL - dorsal anal lobe; DES - dorso-epicranial setae; DPH - dexiophoba; DX - dexiotorma; E - epicranium; ECS - exterior clypeal setae; EFS - exterior frontal setae; EGS - exterior galea setae; ES epicranial suture; F - frons; FE - femur; FS - frontal suture; G galea; GL - glossa; GP - gymnoparia; H - haptomerus; HS - hypopharyngeal sclerite; IVLAS - interior ventral lacinia setae; L - labrum; LA - lacinia; LLGIS - lateral lobe glossae setae; LP - labial palp; LPH - laeophoba; LSTS - lateral setae of stipe; LT - laeotorma; MIS - microsensillae; MP - maxillary palp; MSS - macrosensillae; PE - pedial area; PFS - posterior frontal setae; PLGlS - posterior lateral glossae setae; PLL - pleural lobe; PPH - protophoba; PRS - praescutum; $\mathrm{S}$ - septula; $\mathrm{S} 1,2$, 3 - scissorial teeth; SC - sensory cone; SCL - scutellum; SCT scutum; SN - scissorial notch; SP - spiracle; ST - stipe; TI tibia; TA - tarsus; TG - teges; TR - trochanter; TS - tarsungulus; TT - tibiotarsus; UN - uncus; USME - U-shape median extension; VAL - ventral anal lobes; VSTS - ventral setae of stipe.

\section{RESULTS}

\section{Description of the larva}

Melolonthoid larva, strongly C-shaped but not humpbacked (Fig. 16). Length: 7.5-10 mm. Body milky-white, the head ivory. Mandibles brown, the apex distinctly darker. Setation on body very fine and sparse except for the short dorsal stout setae arranged in transverse rows on dorsa of abdominal segments I-V (Fig. 27).

Cranium (Figs 2, 17, 18) smooth or even faintly reticulate, slightly transverse (mean width: $1.5 \mathrm{~mm}$, length: 1 $\mathrm{mm}$ ). Clypeo-frontal suture straight; two frontal sutures converging, sinuate sub-terminally; each side of the frontal area with 1 anterior frontal seta on the anterior margin, 1 exterior frontal seta and 2 posterior frontal setae distinctly separate; 5 dorso-epicranial setae on each side arranged symmetrically and distinctly separate (Fig. 2); epicranial suture distinct, not prolonged beyond the frontal suture junction. Stemmata absent.

Labrum transverse, symmetrical, coarsely triangular, trilobed anteriorly. The median lobe with 4 setae on the anterior margin; each of the lateral lobes with 5-6 unequal setae (the postero-lateral ones very short), a dozen short setae arranged in a transverse row in antero-median position and, more proximally 2 median macrosensilla distinctly separate.

Clypeus transverse, subquadrangular $(\mathrm{L} / \mathrm{W}=2.65)$, the boundary between pre- and post-clypeus indistinct; anterior angles of frons obtusely round, bearing symmetrically on each side 3 setae arranged as follows: 1 clypeal anterior seta and 2 clypeal external setae, decreasing in size posteriorly. Clypeal area with 2 microsensillae, behind the middle (Fig. 2).

Epipharynx (Figs 4, 20): Clithra present, well sclerotised. Haptomerum strongly convex, the lateral areas lowered; sensorial distal region of haptomerus with 6 regrouped macrosensilla and, more proximally, a semicircular row of 11-13 sensory spots surrounding the protophobae; pedial area sub-oval, surrounded by phobae, showing few flattened microtrichiae oriented posteriorly and arranged approximately in an internal oval row; dexiophoba and laeophoba subsymmetrical, dexiophoba with 7-12 flattened spine-like setae obliquely oriented posteriorly, laeophoba with numerous less well developed spinelike setae. A scarcely sclerotised U-shaped expansion surrounding the two lateral phobae. Acanthoparia with 6-7 stout setae; acroparia with 4 setae. Gymnopariae dis- 

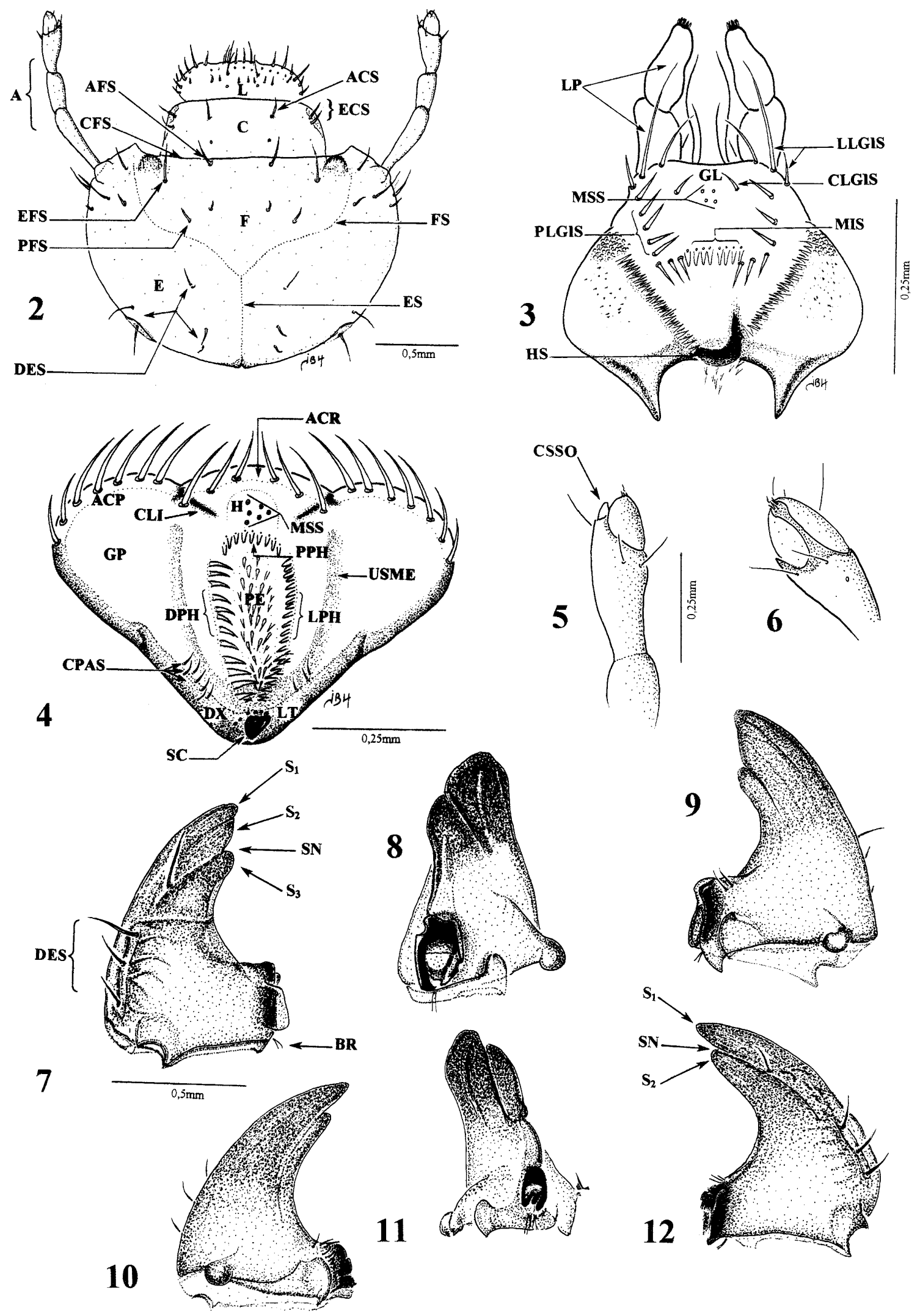

Figs 2-12. Chiron senegalensis Hope \& Westwood, third instar larva. 2 - head, dorsal view; 3 - hypopharynx; 4 - epipharynx; 5 antenna, apical segments, dorsal view; 6 - antenna, apical segments, latero-external view; 7 - left mandible, dorsal view; 8 - left mandible, molar view; 9 - left mandible, ventral view; 10 - right mandible, ventral view; 11 - right mandible, molar view; 12 - right mandible, dorsal view. 

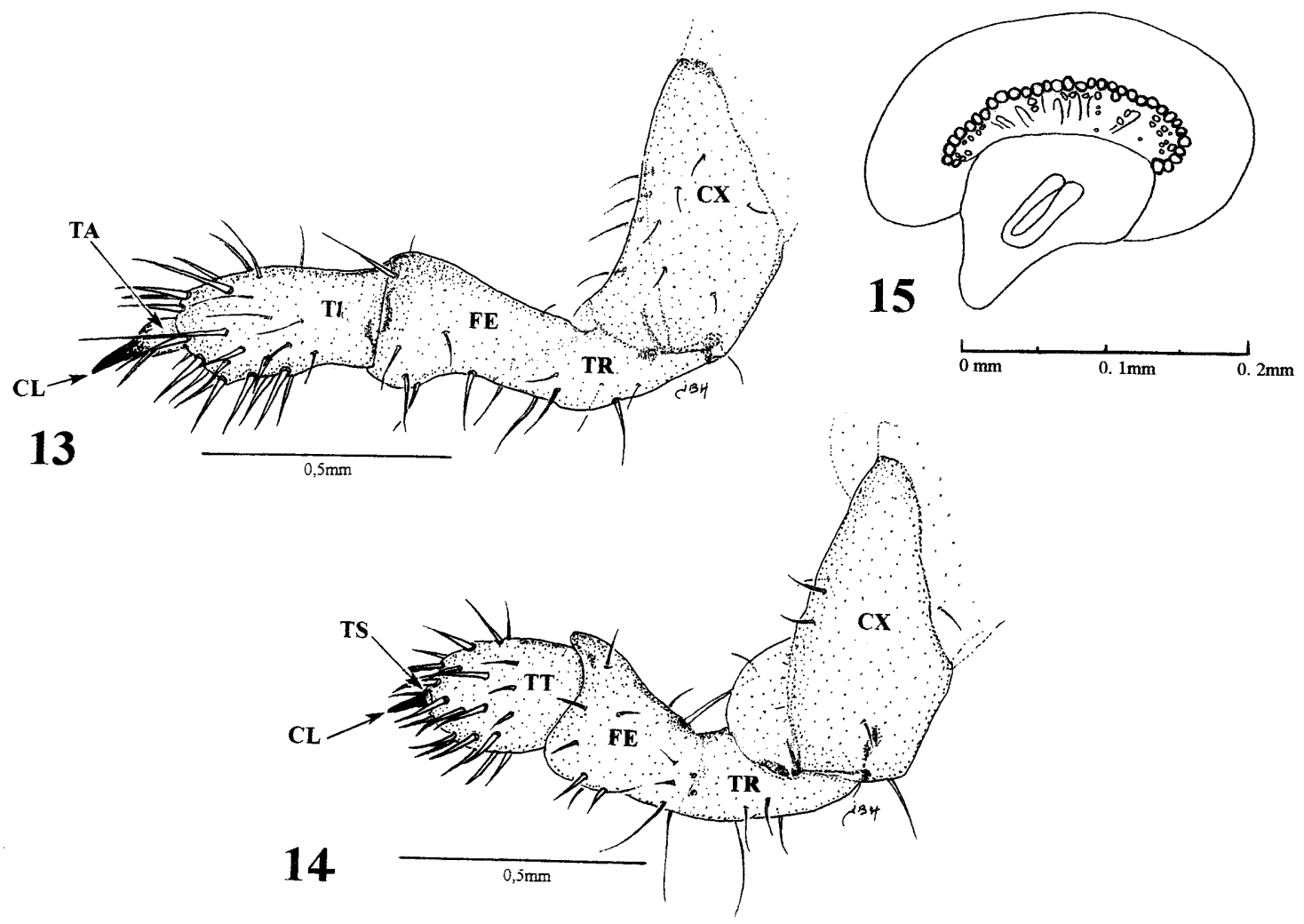

Figs 13-15. Chiron senegalensis Hope \& Westwood, third instar larva. 13 - left prothoracic leg, latero-external view; 14 - left mesothoracic leg, latero-external view; 15 - prothoracic spiracle.

or absent; posterior epitorma absent. A distinct and well developed sense cone with apex oriented posteriorly bearing 4-6 sensory pores. Dexiotorma and laeotorma symmetrical, weakly sclerotised, united medially.

Mandibulae (Figs 7-12) strongly sclerotised, subpyramidal, asymmetrical, both with a ventral process well developed. Scissorial area of left mandible with 3 scissorial teeth (S1-3), and little separation between the apical (S1) and median tooth (S2); S2-S3 separated by a scissorial notch, the third posterior tooth well developed, acute. Molar area with 2 lobes, distal lobe slightly developed, the proximal lobe large, sub-quadrate, concave with the antero-external angle distinctly emarginate. Scissorial area of right mandible with 2 scissorial teeth (S1-2) separated by a scissorial notch. Molar area with 2 lobes, distal lobe rather reduced, the proximal lobe larger with base clearly bilobed, the internal basal lobe more developed proximally. Each mandible with 4 long dorso-external setae, the first three setae arranged in a distinct groove, the fourth seta more distal and placed at the base of the S2-S3 groove. Baso-medial angle with a brustia consisting of 2 short curved setae. No stridulatory organ.

Maxillae (Figs 22, 23): Lacinia and galea slightly sclerotised, distinctly separate. Lacinia larger than galea, the internal angle acute, without uncus, the internal margin rounded and bearing nine setae (6 strong beveled setae and 3 long and acute basal setae). On dorsal view, these setae are bordered with an inner row of 5 fine setae; an inner row of 4 fine setae on ventral side. Galea with a single strong terminal uncus; a row of 4 stiff dorso-apical setae and 3 latero-external setae in ventral view. Dorsal part of stipe with 2 strong setae; the ventral part with 2 long latero-basal setae and 2 similar setae near the proximal margin of galea. Cardo longer than wide. Maxillary articulating membrane bearing sparse setae and a definite transverse squamiform area. No stridulatory organ. Maxillary palpi 4-segmented; palpomeres 1-3 subequal, distal palpomere sub-fusiform with a terminal sensory area bearing unequal microsensillae arranged in a row. Palpifer scarcely distinct.

Labium with a distinct sub-trapezoidal postmentum. Prementum divided into a distal and a proximal prementum. Labial palpi 2-segmented, the proximal palpomere cylindrical, longer than wide, distal palpomere scarcely shorter, sub-conical with apical sensory area bearing few short sensillae. Distal part of prementum transverse, with 2 long median setae and 2 similar setae located between the palpi, the proximal part sub-trapezoidal with 2 long setae arranged postero-laterally.

Hypopharynx (Figs 3, 21) strongly convex, subtrapezoidal, with large base and anterior part narrower, the lateral lobes rounded. The 2 oncyli small, distinctly fused together in a J-shape hypopharyngeal sclerite and located behind the dorsal surface of labial glossae. Glossae with 4 distinct macrosensilla in the middle, surrounded on each side by a longitudinal row of 3-5 stiff setae and linked by a transverse row of approximately 8 spine-like setae. Central lobe of glossae bearing 2 paramedian short setae, the lateral lobes with 2 unequal long setae on each side. 


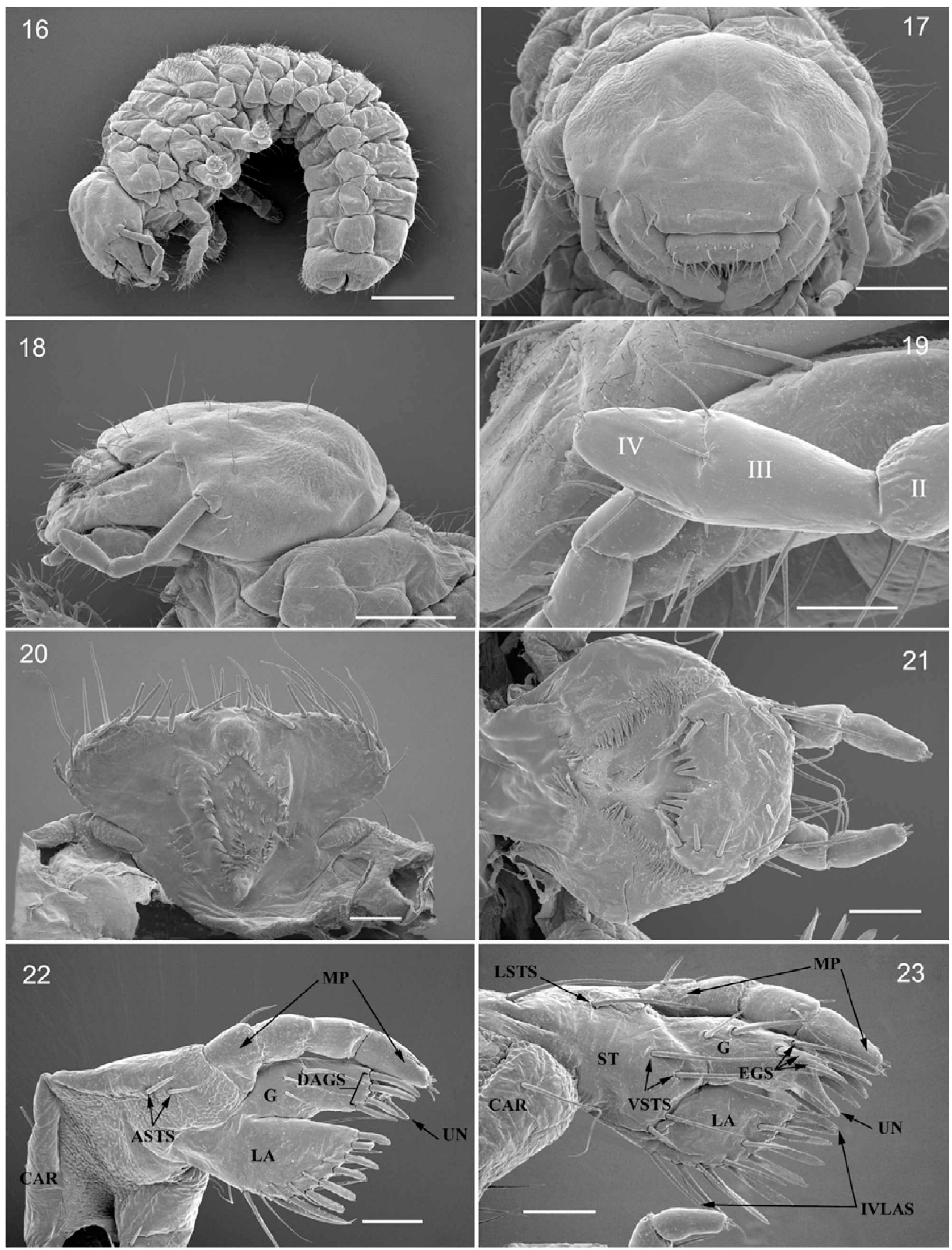

Figs 16-23. Chiron senegalensis Hope \& Westwood, third instar larva, SEM photographs. 16 - third stage larva, left lateral view; 17 - head, frontal view; 18 - head, lateral view; 19 - left antenna, apical part, lateral view; 20 - epipharynx; 21 - hypopharynx; 22 maxillae, dorsal view; 23 - maxillae, ventral view. (Scales: Fig. $16=1 \mathrm{~mm}$; Figs 17, $18=0.5 \mathrm{~mm}$; Figs $19-23=0.1 \mathrm{~mm}$ ). 

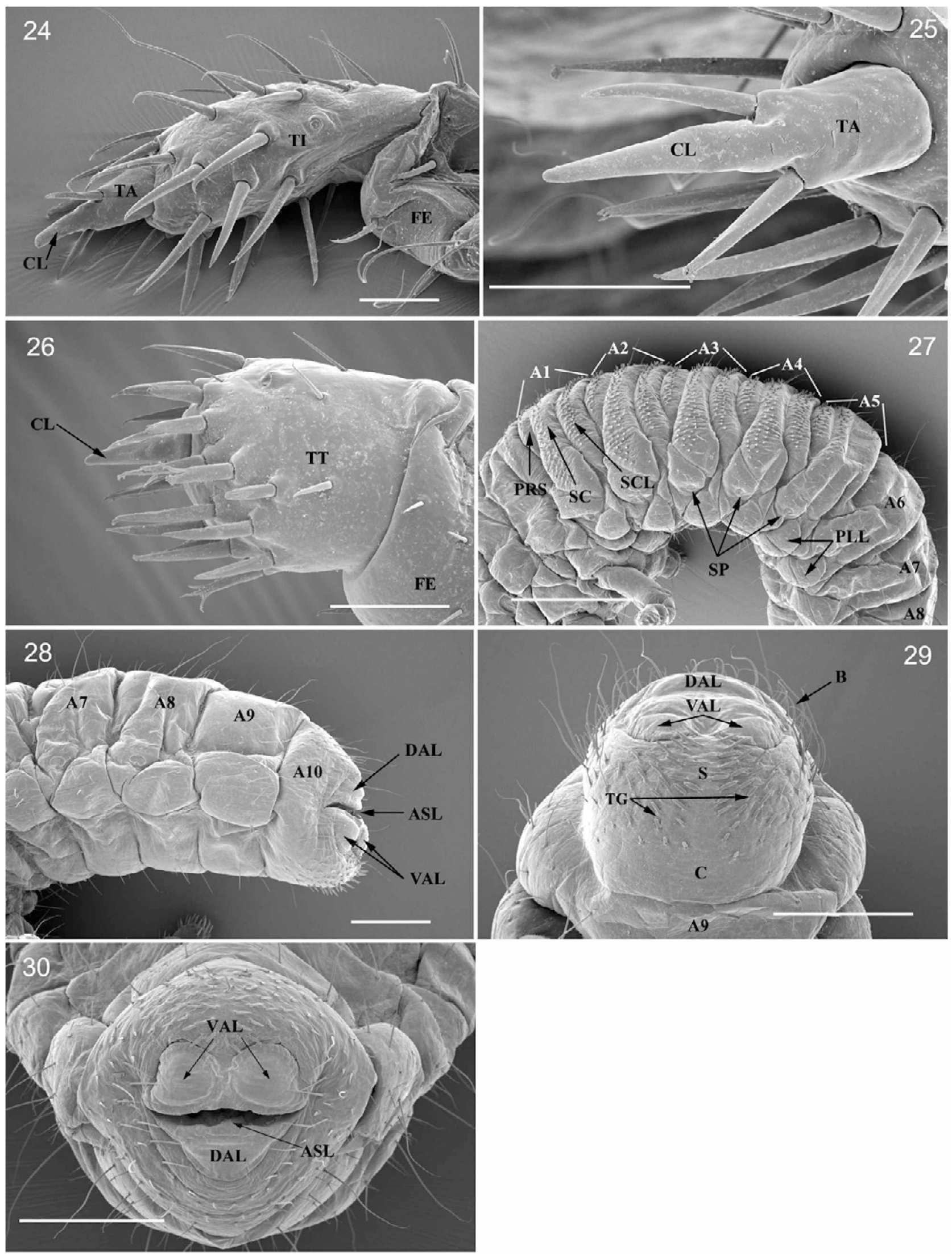

Figs 24-30. Chiron senegalensis Hope \& Westwood, third instar larva, SEM photographs. 24 - prothoracic leg, lateral view; 25 prothoracic leg, detail of apical part; 26 - metathoracic leg, apical part, lateral view; 27 - abdomen, latero-dorsal view; 28 - raster and last abdominal segments, lateral view; 29 - raster, ventral view; 30 - last abdominal segment, caudal view. (Scales Figs $24-26$ $=0.1 \mathrm{~mm}$; Fig. $27=1 \mathrm{~mm}$; Figs $28-30=0.5 \mathrm{~mm}$ ). 

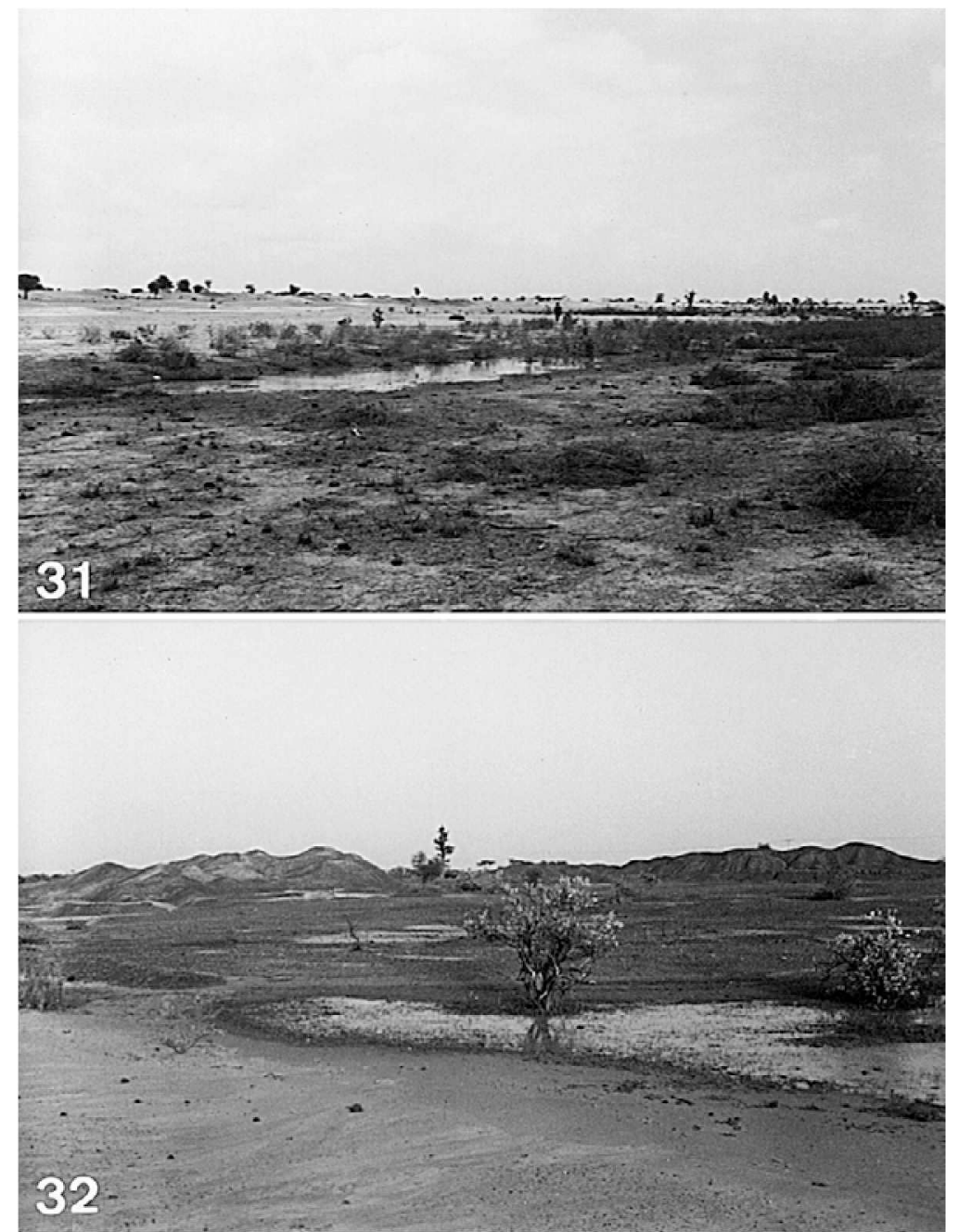

Figs 31-32. Senegalese biotopes where the larvae of Chiron senegalensis Hope \& Westwood were collected. 31 - Richard-Toll site; 32 - Dagana site. (Photos J. B. Huchet).

Antennae 4-segmented; antennomeres 1-3 well developed; the first antennomere cylindrical, very elongated, slightly pubescent, twice length of second, the third antennomere with 4-5 apical setae arranged in circle and with a distinct dorsal sensory cone; distal antennomere markedly shorter than the first three ones (Figs 5, 6, 19), sub-conical, latero-dorsally inserted on the third segment and appearing as an appendage of this segment, with an apical sensory area bearing several microsensillae.

Prothorax without projecting anterior processes or sclerotised plates; dorsum of prothorax divided into 2 scarcely distinct annulets bearing few sparse setae; dorsa of meso- and metathorax divided into: prescutum, scutum and scutellum; scutellum of metathorax bearing a row of approximately 14 short stout setae.

Abdominal segments 1-5 each with dorsum divided into prescutum, scutum and scutellum, each with one or two transverse rows of short stout setae (except the scutellum of A5 bearing only sparse long setae) (Fig. 27). Prescutum of A1 bearing one single row of 16 setae, prescutum of A2-A5 with 2 rows of 19-20 setae; scutum of A1-A2 with two rows of 90-100 setae, scutum of A3-A4 with 65-70 setae, scutum of A5 with 15 short setae, each scutum with also a proximal transverse row of about ten unequal fine setae; scutellum of A1-A2 with 56-60 setae, scutellum of A3-A4 bearing 46-48 setae; abdominal segments A6-A8 divided into 2 weakly distinct annulets, segments A9 and A10 not divided (Fig. 28). Each pleural lobe with 4 fine setae in transverse row.

Legs (Figs 13, 14, 24, 25, 26) well developed, quite strong, all four-segmented. Trochanter and femur nearly fused. Prothoracic pair slightly longer than meso- and metathoracic pairs. Prothoracic pair with a distinct tibia and an elongated tarsus bearing a strong claw and 2 strong setae on each side (Fig. 25). Meso- and metathoracic pairs shorter and squatter; tibia and tarsus fused in a tibiotarsus, with the claw inserted on a weak bulge. No stridulatory organs.

Spiracles cribriform (Fig. 15), the respiratory plate reniform bearing approximately 3-9 confluent "cavities" arranged in about 20-30 semicircular rows; concavities on the respiratory plates of thoracic spiracles facing posteriorly, those of abdominal segments facing ventrally. Respiratory plates of spiracles not constricted and with no large surrounding bulla. 
Raster (Figs 29, 30) with teges bearing approximately 28 short spike-like setae on each side oriented laterally, without sclerites at base; septula narrow, scarcely distinct; barbula consisting of rather numerous long setae; campus occupying anterior third part of A10; anal opening transverse, slightly curved, surrounded by fleshy lobes: A single upper lobe and 2 tangent lower lobes.

Remarks. Among the material studied there were many living larvae that showed distinct localised lesions due to parasitic fungi, mostly on legs, antennae and palpi. Larvae that had died of fungal infection were not found in the field.

\section{DISCUSSION}

\section{Main differential characteristics of Chiron larvae}

The following larval characters strongly indicate the outstanding position of Chiron: the shape of the lacinia, very large and without terminal uncus, does not correspond to that of any other taxon in the Scarabaeoidea. In Chiron the maxillae, mandibles and legs bear no stridulatory organ or stridulatory area. Several other families also lack a stridulatory apparatus on different anatomical parts. For example, a maxillary stridulatory area is absent in Lucanidae; a mandibular stridulatory area is present in most Scarabaeoid larvae but not in Trogidae; and a stridulatory apparatus on legs is a variable feature of different families of Scarabaeoidea (Browne \& Scholtz, 1999). In the present case, the total absence of such organs in Chiron could be interpreted as an important distinctive character.

The 3rd and 4th antennomeres are intimately fused antero-laterally, hence they are not clearly distinct. A similar feature (secondary fusion of the 3rd and 4th antennomeres) is also recorded for some Hybosoridae (Scholtz, 1990).

Last, the morphology of the legs is quite different from that of other Scarabaeoidea larvae: very strong or even squat legs (especially the meso- and metathoracic legs, the anterior ones being more slender), with a terminal uncus quite short and strong, bearing two spine-like setae on each side (in Aphodiidae, Aegialiidae, Aulonocnemidae and also in Trogidae, the legs are always elongated, with fine and prominent claws). The structure of legs may be an adaptation for burrowing (some Melolonthidae and Cetoniidae larvae have similar shaped legs). In Chiron, however, the legs are longer relative to body size. Another remarkable feature is the distinct reduction of the meso- and metathoracic legs. In Chiron, the prothoracic tibiae are elongated and bear a distinct tarsus, each with a strong apical claw. A notable regression occurs in the meso- and metathoracic legs where the tibiae and the tarsi appear to be reduced and intimately fused, forming a tibiotarsus. In fact, the terminal claw is inserted on a weak bulge, which bears 2 strong sensory setae laterally (tarsungulus). Finally, the femur and trochanter of all legs are distinctly fused and the femur appears to be reduced. Similar features exist in some Geotrupidae (Paulian, 1939).

Other groups of Scarabaeoidea have reduced legs, especially the Passalidae (metathoracic legs unsegmented and reduced to a stridulatory organ) and even some Geotrupidae, where all legs are equally 3 -segmented. This does not imply close relationships between these taxa but emphasises some major trends in the reduction of legs in Scarabaeoidea.

\section{Taxonomic relationships}

A complete phylogenetic study will be carried out later to confirm or invalidate our conclusions on the relationships of Chiron within the Scarabaeoidea based on the larval morphology of Chiron senegalensis.

In order to determine how other authors have placed Chiron $^{1}$ among the other members of the superfamily, we have referred to publications with dichotomic keys (Hayes, 1928; Böving \& Craighead, 1931; Van Emden, 1941; Janssens, 1947; Ritcher, 1966; Paulian \& Baraud, 1982). Depending on the larval characters used by these authors, the results differ (however, in most cases, not all characters are used) and are therefore inconclusive.

Depending on the key, the taxonomic placement of Chiron appears to be: close to Aphodiinae, according to the larval characters used by Van Emden (1941), Ritcher (1966) and Paulian \& Baraud (1982); between Trogidae and Ceratocanthidae (Acanthoceridae sensu auct.), according to the larval characters used by Böving \& Craighead, (1931); between Trogidae and Aphodiinae, following Janssens (1947); with affinities with Scarabaeidae, but also intermediate between Lucanidae and Trogidae (with these latter, in regard with the trilobed anal segment), according to the key of Hayes (1928).

Although Chiron share several features with some of the above taxa, they are not clearly related to any of these groups. The main larval characters it has in common with these groups are most often present in Laparostict ${ }^{2}$ Scarabaeoidea: body cylindrical (not hump-backed ${ }^{3}$ ), maxilla with galea and lacinia separated, antenna 4-segmented, tormae fused medially, legs 4-segmented with a well developed claw. According to these characters, Chiron larvae can be placed unequivocally among the less specialised Scarabaeoidea. This is in concordance with adult morphology since many characters support this conjecture: trilobed-type aedeagus (D'Hotman \& Scholtz, 1990), 8 pairs of functional spiracles, presence of the

\footnotetext{
1 The study of larval material of other genera of Chironidae (e. g. Theotimius Huchet or Amphiceratodon Huchet) could confirm or even refute the conclusions here presented.

2 The former separation of Scarabaeoidea into Laparosticti and Pleurosticti is controversial since the adults of some of the families (e.g. Glaphyridae, Pachypodidae or Aclopidae) cannot be related to either of them.

${ }^{3}$ The typical hump-backed body is one of the main characteristics of Scarabaeidae larvae (dung beetles) associated with their habit. A similar larval character occurs in some Geotrupidae.
} 
BMP-CuA brace at the wing base (J. Browne, pers. com.).

The fact that some major taxa were initially removed and thus not considered (Scarabaeidae, Geotrupidae...) does not imply a posteriori a relationship with Chironidae since some of the distinctive characters used in the keys (e.g. hump-backed body) are the result of secondary adaptations.

The relationships with Aphodiinae is based on the labrum being trilobed anteriorly in both groups. This character is often present in other taxa (some Pleocomidae, Scarabaeidae - particularly some Coprinae -, Aulonocnemidae or even Lucanidae); as it is not always present in some groups, its taxonomic value is questionable. The second feature is the number and disposition of the anal lobes (trilobed). This last character also occurs in Trogidae and Lucanidae but in those groups, the anal slit is generally $\mathrm{Y}$-shaped. In Chiron, the lower anal lobe is divided into two distinct lobes, as recorded in some Aphodiidae (Eupariinae or even Psammodinae) (Ritcher, 1966). If we accept that the shape of the lower anal lobes determines the relationships between Chiron and Aphodiidae or Aegialiidae, the latter cannot be retained as a related group (one single lower anal lobe in Aegialiidae). Lastly, the 2-lobed condition appears to be a variable character in the Aphodiidae (e.g. 4 lower anal lobes in Aphodius (Colobopterus) erraticus (Linnaeus, 1758): Jerath, 1960; Ritcher, 1966: 27) and is insufficient support for a close relationship between Aphodiidae and Chironidae.

Aphodiidae and Aegialiidae or even Aulonocnemidae (Paulian \& Lumaret, 1974) are distinct homogeneous groups with clear larval affinities, particularly some features of the epipharyngeal structure: remarkably well developed epitorma and strongly sclerotised tormae. Moreover, the shape of the epipharynx is more or less constant in these families. The importance of the epipharynx for distinguishing between the major groups of Scarabaeoidea has not to be stressed today. In the present case, the peculiar triangular shape of the epipharynx, the absence of epitorma and the structure and slight sclerotisation of the tormae in Chiron, is a very distinctive and unique feature in the Scarabaeoidea. A similar weakly developed epitorma and the lack of a stridulatory apparatus on the legs have been pointed out on Trogidae but, according to Scholtz \& Lumaret (1991), the larvae of this family have many other distinctive and primitive characters (antennae 3-segmented, ocelli always present, galea 2-segmented or even spiracles with a closing apparatus), which probably do not support a close affinity with Chiron. While sharing several features with other Scarabaeoidea families considered to be phylogenetically primitive (Scholtz, 1990), Chiron has a combination of distinct characters that are peculiar to the taxon. The structure of the epipharynx (triangular shape without epitorma) as well as the shape of the lacinia, the modifications to the legs or even antennae strongly indicate the very isolated position of this genus and are sufficiently distinctive to justify a particular status within the Scarabaeoidea.

Nevertheless, from the point of view of larval morphology, the systematic position of Chironidae within the superfamily remains still uncertain. This is often the case in small mono- or paucigeneric families (e. g. Aclopidae, Pachypodidae, Belohinidae). A complete cladistic analysis based on larval and adults characters will be carried out in order to determine the relationships between Chironidae and other Scarabaeoidea; at this time the choice of possible sister groups has not yet been completely made.

ACKNOWLEDGEMENTS. We thank Dr R. Paulian for his helpful comments on the manuscript, and especially our colleague Paul E. Skelley (Florida State Collection of Arthropods) for taking the SEM photographs. Special gratitude is expressed to T. Branco (Porto) for his helpful comments and improving the English. This work was partly supported by a grant from the French Entomological Society, France (Germaine Cousin legacy).

\section{REFERENCES}

Balthasar V. 1963: Monographie der Scarabaeidae und Aphodiidae der palaearktischen und orientalischen Region, Vol. 1. Verl. Tsch. Akad. Wiss., Praha, 391 pp.

Böving A.G. 1936: Description of the larva of Plectris aliena Chapin and explanation of new terms applied to the epipharynx and raster. Proc. Entomol. Soc. Wash. 38: 169-185.

Böving A.G. \& Craighead F. C. 1931: An illustrated synopsis of the principal larval forms of the order Coleoptera. Entomol. Amer. 11: 1-351.

Browne D.J. \& Scholtz C.H. 1999: A phylogeny of the families of Scarabaeoidea (Coleoptera). Syst. Entomol. 24: 51-84.

Carayon J. 1969: Emploi du noir chlorazol en anatomie microscopique des insectes. Ann. Soc. Entomol. Fr. (N.S.) 5: 179-193.

CARNE P.B. 1951: Preservation techniques for Scarabaeid and other insect larvae. Proc. Linn. Soc. N. S. W. 76: 26-30.

D'Hotman D. \& Scholtz C.H. 1990: Phylogenetic significance of the structure of the external male genitalia in the Scarabaeoidea (Coleoptera). Entomol. Mem. 77: 51 pp.

EMdEN VAN F.I. 1941: Larvae of British beetles, 2. A Key to the British Lamellicornia larvae. Entomol. Monthly Mag. 77: 117-127, 181-192.

Fabricuus J.C. 1798: Supplementum Entomologiae Systematicae. Proft et Storch, Hafniae, $572 \mathrm{pp}$.

FABRICIUS J.C. 1801: Systema Eleutheratorum secundum Ordines, Genera, Species, adjectis Synonymis, Locis, Observationibus, Descriptionibus, Vol. 2. Impensis Bibliopolii Academici novi, Kiliae, $687 \mathrm{pp}$.

HAYES W.P. 1928: The epipharynx of lamellicorn larvae (Coleopt.) with a key to common genera. Ann. Entomol. Soc. Amer. 21: $282-306$

HuChet J.B. 2000: Scission du genre Chiron Mac Leay, 1819 et description de deux nouveaux genres de la famille des Chironidae (Coleoptera, Scarabaeoidea). Ann. Soc. Entomol. Fr. 36: $3-28$.

HuChet J.B. 2002a: Révision du genre Amphiceratodon Huchet 2000 (Coleoptera: Scarabaeoidea: Chironidae). Bull. Soc. Entomol. Fr. 107: 61-78. 
Huchet J.B. 2002b: Révision du genre Theotimius Huchet, 2000 (Coleoptera, Scarabaeoidea: Chironidae). Ann. Soc. Entomol. Fr. (in press).

ILLIGER K. 1801: Magazin für Insektenkunde 1, Braunschweig, K. Reichard ed., VIII + 1-260.

Janssens A. 1947: Contribution à l'étude des Coléoptères lamellicornes de la faune belge. 1. Table de détermination générique des larves. Bull. Mus. Royal Hist. Nat. Belg. 23: 1-14.

Jerath M.L. 1960: Notes on larvae of nine genera of Aphodiinae in the United States (Coleoptera: Scarabaeidae). Proc. U. S. Nat. Mus. 111: 43-94.

Kim J.I. \& Lumaret J.-P. 1988: Les larves du genre Onthophagus Latreille, 1802. 1. Caractères communs et variations (Coleoptera: Scarabaeidae). Elytron 2: 51-61.

Latreille P.A. 1817: Les Crustacés, les Arachnides et les Insectes. In: Cuvier G. (ed.): "Le Règne Animal Distribué d'après son Organisation pour Servir de base à l'Histoire Naturelle des Animaux, Vol. 3. Deterville, Paris, xxx +653 pp.

Latremle P.A. 1825: Familles Naturelles du Règne Animal, Exposées Succinctement et Dans un Ordre Analytique avec l'indication de Leurs Genres. J.-B. Baillière, Paris, $570 \mathrm{pp}$.

Latreille P.A. 1829: Crustacés, Arachnides et partie des Insectes. In: Cuvier G. (ed.): "Le Règne Animal Distribué d'après son Organisation pour Servir de base à l'Histoire Naturelle des Animaux et d'introduction à l'Anatomie Comparée, Vol. 4. Deterville, Paris, 541 pp.
Mac Leay W.S. 1819: Horae Entomologicae, or Essai on the Annulose Animals, Vol.1. S. Bagster, London, $524 \mathrm{pp}$.

PaUlian R. 1939: Les caractères larvaires des Geotrupidae (Col.) et leur importance pour la position systématique du groupe. Bull. Soc. Zool. Fr. 64: 351-360.

Paulian R. 1976: Les Chironidae (Col. Scarab.) de Madagascar. Bull. Mens. Soc. Linn. Lyon 45: 236-239.

Paulian R. 1988: Biologie des Coléoptères. Lechevalier ed., Paris, $719 \mathrm{pp}$.

Paulian R. \& Baraud J. 1982: Faune des Coléoptères de France 2, Lucanoidea et Scarabaeoidea. Lechevalier ed., Paris, $473 \mathrm{pp}$.

Paulian R. \& Lumaret J.-P. 1974: Les larves des Scarabaeidae: 4. Le genre Aulonocnemis Schaufuss (Col.). Bull. Soc. Entomol. Fr. 79: 233-240.

Ritcher P.O. 1966: White Grubs and their Allies. A Study of North American Scarabaeoid Larvae. Studies in Entomology. No. 4. Oregon State University Press, Corvallis, 219 pp.

Scholtz C.H. 1990: Phylogenetic trends in the Scarabaeoidea (Coleoptera). J. Nat. Hist. 24: 1027-1066.

Scholtz C.H. \& Lumaret J.-P. 1991: Description of European Trox F. larvae (Coleoptera: Trogidae). Coleopt. Bull. 45: $317-322$.

Verdú J.R. \& Galante E. 1997: Aphodius brasiliensis Castelnau (Coleoptera: Aphodiidae). Larval morphology and notes on biology. Coleopt. Bull. 51: 378-383.

Received June 6, 2001; revised November 1, 2001; accepted February 12, 2002 